International Journal of Agriculture, Environment and Bioresearch

Vol. 4, No. 06; 2019

ISSN: $2456-8643$

\title{
ANALYSIS OF THE EXTENSION NEEDS OF YAM FARMERS FOR INCREASED PRODUCTIVITY IN RIVERS AND IMO STATES, NIGERIA
}

\author{
${ }^{1}$ B. A. Odinwa, ${ }^{2}$ B. I. Isife and ${ }^{3}$ F. E. Nlerum \\ ${ }^{1}$ Department of Agricultural Education, Federal College of Education (Technical), PMB 11, Omoku, Rivers State. \\ ${ }^{2 \& 3}$ Department of Agricultural Extension and Rural Development, Rivers State University, Nkpolu, Port Harcourt.
}

http://doi.org/10.35410/IJAEB.2019.4469

\begin{abstract}
This study focused on the analysis of the extension needs of yam farmers for increased productivity in Rivers and Imo States. The specific objectives were to: i) describe the socioeconomic characteristics of yam farmers in Rivers and Imo states, ii) find out the factors that will increase yam productivity in the areas. Descriptive survey design was used to examine the cross section of the population. A total of 587 respondents were selected from 18 LGAs in Rivers and Imo States, through proportionate random sampling technique and used in this study. Primary data obtained through structured questionnaire were analyzed, using percentage, arithmetic means and weighted mean scores. Ordinary Least Square Regression Analysis and z-Test were used for test of significance. The findings showed that majority of the farmers in the study areas were male (61\%), who were middle adult (46 years old), married men $(60.8 \%)$ and were more of part-time (58\%). It indicated a mean annual income of N150,835.00 for the farmers in the areas of study and once per month contact with extension agents (27.1\%) was dominant in the areas. It also showed that dedicated extension agents $(M=3.76)$, accessible credit facilities $(M=3.63)$, and introduction of non stake yam varieties $(\mathrm{M}=3.48)$ among others will increase yam productivity in the areas. The study therefore recommended among others that: 1) The youths should be encouraged and armed financially to meaningfully engage in yam production by the state governments. 2) Only qualified and dedicated extension agents should be employed to handle technical extension services especially in yam production in these states. 3) Special but accessible credit facilities should be given to yam farmers on-the-farm only, in these two states and the mechanism for its use be assigned to agro extension professionals
\end{abstract}

Keywords: Extension Needs, Yam, Farmers, Increase, Productivity.

\section{INTRODUCTION}

Extension is the organized exchange of information and the purposive transmission of skills, ideas, technology and novelty from their sources of origin to the rural sectors in order to capacitate the rural dwellers for continuous relevance in a viable economy. Agricultural extension provides the avenue in which farmers and rural people are helped to improve their desired living conditions through guided farming, processing and marketing of farm products. Agricultural extension system refers to the total framework of extension organizations' action as medium through which educative and problem solving innovations are delivered to the proper 
audience by a dedicated agent (Akinola, Issa, \& Sanni, 2011). It is obvious that the transfer of information and skills has existed and has been undergoing transformation since the emergence of commercial agriculture. The practice today according to the same source, is dissimilar in that the process is dominated by organizations, and its scope has extended from disjointed local events to a complicated, large scale and even worldwide activity.

Agriculture has been a key element of Nigerian economy, as it is in other parts of the world. It currently contributes about $41 \%$ of the Nigerian Gross Domestic Product (GDP), employing about $70 \%$ of the active labour force (Stephen, 2009). According to him, the sector has traditionally been expected to fulfill such roles as providing food for the teeming population, generates foreign exchange earnings, employs part of the labour force, and provides income for the farm families to live wealthy and healthy. However, the sector has significantly underperformed its potentials because of leap services given to the sector by our past governments. It is characterized by food shortages, inconsistent agricultural policies and import of large quantities of rice, wheat, sugar, meat and other finished agricultural products.

The mission of Extension is to extend handy education to rural people. The emphasis in extension education is on reaching the people to help themselves and live better through guided farming, processing and marketing of farm products (Uwe, 2002).

A sustained agricultural extension practice has been seen as a panacea to all agricultural and technological problems of the developed nations of the world like America, Europe, Germany, etc. It is expected that third world countries should properly and practically embrace it for their own success.

This is because agricultural extension is geared towards bringing to the rural people the knowledge and help that will enable them farm more efficiently and to increase their income; encouraging the farmers to grow their own food, set a good habit and live well. It helps the members of the farm family to a larger appreciation of the opportunities, beauty and privileges of rural life, and to detect something about the world in which they live. It also promotes the sociocultural, recreational, intellectual and spiritual lives of the rural people; placing opportunities before rural people whereby they may develop all their native talents through work and leadership positions, and building a rural citizenry that is proud of its outlook, capable, efficient, with a love of home and community in their heart (Nwachukwu, 2013). This is possible to achieve in a nation that perceives the value of food and the place of farmers in an economy and strive to secure by any means both the food and the producer (the farmer).

In Rivers and Imo states, various corporations and agencies have engaged in agricultural extension in both tuber/root crops and livestock production like Shell Petroleum in Agricultural Extension, Nigeria Agip Oil Company (NAOC) Limited as Green River Project (GRP), Total E\&P as Seed Multiplication Centre (SMC) and Ministries of Agriculture as Agricultural Development Programme (ADP), in response to the Nigerian Federal Government's directives in 1986 to all foreign oil companies and large corporations to engage in agricultural development programmes within their areas of operation, which is achievable through agricultural extension practices (Odinwa, Emah \& Odinwa, 2016). But how well and how much have the extension 
programmes of these corporations and agencies cover yam productions, its value chains and the farmers in Rivers and Imo states?

Yam which is one of the essential tuber crops is a traditional food crop appreciated for its taste and cultural role in West Africa, especially in Nigeria as the world largest producers of yams, with annual production estimated at 45 million metric tons (UN Food \& Agriculture Organization, 2017). Yam is regarded as a socio-cultural crop and is becoming expensive in urban areas as production has not kept pace with population growth leading to demand rising over and above supply (Kushwala \& Polycarp, 2001).

A recent study on yam has shown that absolute level of production in West Africa and the World has remained static for three decades (Scott, Rosegrant \& Bokanga, 2000). The static or declining trend may not be unconnected with production resources which are not being resourcefully utilized leading to low productivity (Fasasi, 2006).

The main types of yam (Dioscorea spp.) such as the white yam (D. rotundata), yellow yam (D. cayenensis), water yam (D. alata), three leaf yam (D. dumetorum) and the aerial yam (D. bulbifera) grow best in the wet-and-dry tropics of West Africa, where Rivers and Imo states are situated. Yams have very high yield potential, although their protein, mineral and vitamin contents are generally low compared to cereals. However, yams contain up to $6 \%$ protein of good quality and provide some minerals and vitamin C. They are recognized for their high dry matter production, with a potential of (2.1 tons per hectare) from underground storage organ (O'Hair, 1996).

Yam has been termed under-exploited and worthy of considerably more research input. In fact, this crop remained neglected in terms of scientific input until the establishment of the International Center for Tropical Agriculture (CIAT) in Colombia 1967, the International Institute for Tropical Agriculture (IITA) in Nigeria in 1968, and the International Potato Center (CIP) in Peru in 1971 (O'Hair, 1996). Even with the establishment of these International centres and extension organizations/agencies, yam production is still under-exploited in the states where they are highly consumed as staple and practiced as major occupation by the farmers. From available evidences, yam farms are still at subsistence level in the area with vast fertile lands and the outputs are very low to meet the local demand for them.

Understanding the extension needs of yam farmers (i.e. the things required by farmers from extension services to function as famers and things required by extension agencies to render their duties to yam farmers properly) becomes necessary in order to ensure maximum production of yam tubers and their attendant value chains. This has to be explored since extension creates the required interest and motivation beside the necessities of this crop for farmers to adopt and improve their productivity and better their lives (Redmond, 2010).

Therefore, this study was designed specifically to:

i. describe the socio-economic characteristics of yam farmers in Rivers and Imo states, and

ii. assess the factors that will increase productivity of yam farmers in the areas; 
Two hypotheses stated in a null form were formulated to guide the study as:

1. Ho: Socio-economic characteristics of yam farmers do not affect the extension needs of yam farmers in these two states.

2. Ho: Factors that will increase the productivity of yam farmers do not differ significantly between the two states.

\section{METHODOLOGY}

Rivers and Imo states are among the 36 States in the Federal Republic of Nigeria, located in South-South and South-East respectively. The States have vast land and water bodies which represent those of the humid and tropical forest climate zones, with over 8,000,000 million people. Agriculture was and is still the primary occupation of the people of these two states even in the face of crude oil and gas exploration and exploitation. Crops that are used to low base saturated and low solar radiation such as tuber crops (yam, sweet potato, cocoyam, cassava,), rice, maize, vegetables, some grasses and pasture legumes are grown in this zone for better utilization of the soil and inputs such as fertilizer. The main economic activities of these states include farming, fishing, trading, beside crude oil and gas businesses.

The study adopted a descriptive survey research which involves examining a cross-section of the population of the registered yam farmers of the selected extension agencies providing the extension services in various Local Government Areas (LGAs) in the two states, for possible policy generation and economic intervention in the areas. Eighteen (18) LGAs, Nine (9) each from the two states were purposively and randomly selected to give the selected LGAs equal chances of participation. A proportionate random sampling which permits the same sample fraction from each stratum - extension agency per LGA (Ladele \& Chah, 2014) was used to select five hundred and eighty-seven (587 respondents - comprising 316 and 271 from Rivers and Imo States respectively). Also, One (1) extension agency each was purposively selected from each of the LGAs, based on the presumed fact that these extension agencies could provide the needed information in yam production. Primary data used in this study were collected through the administration of a structured questionnaire and interview schedules. The questionnaires were designed in 'yes and no' format to cover socio-economic characteristics of the respondents. The other objective was designed using a four point Likert type rating scale.

Both descriptive and inferential statistics were employed to analyze the data. Descriptive statistics such as percentage, arithmetic mean and weighted mean scores derived from the four point Likert type rating scales were used. The inferential statistics used were Regression analysis and $\mathrm{Z}$ - test to test the hypotheses.

Hypothesis 1 was done using ordinary least square regression model which was explicitly represented as:

$\mathrm{Y}=\mathrm{f}\left(\mathrm{x}_{1} \mathrm{x}_{2} \mathrm{x}_{3} \mathrm{X}_{4} \mathrm{X}_{5} \mathrm{X}_{6} \mathrm{X}_{7} \mathrm{X}_{8} \mathrm{X}_{9} \mathrm{x}_{10} \mathrm{X}_{11} \mathrm{x}_{12}+\mathrm{e}\right)$

Where $\mathrm{Y}=$ needs of yam farmers; $\mathrm{x}_{1}=\mathrm{sex} ; \mathrm{x}_{2}=$ age (years); $\mathrm{x}_{3}=$ marital status; $\mathrm{x}_{4}=$ education; $\mathrm{x}_{5}=$ nature of farming; $\mathrm{x}_{6}=$ farm size $(\mathrm{ha}) ; \mathrm{x}_{7}=$ household size $(\mathrm{no}) ; \mathrm{x}_{8}=$ types of $\mathrm{yam} ; \mathrm{x}_{9}=$ 
cropping practice; $\mathrm{x}_{10}=$ annual income $(\AA) ; \mathrm{x}_{11}=$ contact with ext agent; $\mathrm{x}_{12}=$ experience (years); $\mathrm{b}_{0}=$ constant; $\mathrm{e}=$ error term.

Four functional forms of ordinary least square regression model were built-in. These include: linear, semi-log, double log (Cobb Douglas) and exponential functions and are presented as follow:

$\mathrm{Y}=\mathrm{f}\left(\mathrm{x}_{1} \mathrm{x}_{2} \mathrm{x}_{3} \mathrm{x}_{4} \mathrm{x}_{5} \mathrm{x}_{6} \mathrm{x}_{7} \mathrm{x}_{8} \mathrm{x}_{9} \mathrm{x}_{10} \mathrm{x}_{11} \mathrm{x}_{12}+\mathrm{e}\right)$

Linear function:

$\mathrm{Y}=\mathrm{b}_{0}+\mathrm{b}_{1} \mathrm{x}_{1}+\mathrm{b}_{2} \mathrm{X}_{2}+\mathrm{b}_{3} \mathrm{X}_{3}+\mathrm{b}_{4} \mathrm{X}_{4}+\mathrm{b}_{5} \mathrm{X}_{5} \ldots \ldots \ldots+\mathrm{b}_{12} \mathrm{X}_{12}+\mathrm{e}$

Semi-log function:

$\mathrm{Y}=\operatorname{Inb}_{0}+\mathrm{b}_{1} \operatorname{In} \mathrm{x}_{1}+\mathrm{b}_{2} \operatorname{Inx_{2}}+\mathrm{b}_{3} \operatorname{Inx_{3}}+\mathrm{b}_{4} \operatorname{In} \mathrm{x}_{4} \mathrm{~b}_{5} \operatorname{Inx} \mathrm{x}_{5}$

Double log function:

$\operatorname{InY}=\operatorname{Inb}_{0}+b_{1} \operatorname{In} x_{1}+b_{2} \operatorname{In} x_{2}+b_{3} \operatorname{Inx} x_{3}+b_{4} \operatorname{In} x_{4}+b_{5} \operatorname{In} x_{5}$

Exponential function:

InY $=b_{0} x_{1} x_{1}+b_{2} x_{2}+b_{3} x_{3}+b_{4} x_{4}+b_{5} x_{5}$. $+\mathrm{b}_{12} \mathrm{X}_{12}+\mathrm{e}$

The choice of the best functional form was based on the magnitude of the $\mathrm{R}^{2}$ value, the significance, size and the signs of regression coefficient as they relate to apriori expectation.

Test of Hypothesis 2 was done using $\mathrm{Z}$ - test. The inferential statistics used was to ascertain if the extension needs of yam farmers in the two states (Rivers and Imo) differed significantly. It was tested at 0.05 alpha level of significance. Where z-calculated is greater than the alpha level (0.05), the null hypothesis was rejected; otherwise, the result was accepted.

\section{RESULT AND DISCUSSION}

\section{Socio-Economic Characteristics of Yam Farmers in Rivers and Imo states}

Result of the socio-economic characteristics of the respondents (Table 1) showed that men dominated in yam production $(61 \%)$ in the two states. This is because yam is regarded as a king among crops resulting from technicalities involved in its cultivation and maintenance as well as the honour accorded to it as a festival crop of rank by the farmers. This may have made men to patronize yam production more than the women in these two states. This result agreed with IITA (1982) report which gave credence to the claim that 'Nigeria, the world's largest yam producer, considers yam to be a "man's property" and traditional ceremonies still accompany yam production indicating the high status given to the plant'. This finding did not negate the fact that women are the actual operators of the agricultural industry in Africa as pointed out by Odinwa and Nlerum (2015). It showed a mean age of the respondents to be 46 years old, implying that it is the middle adult and above that operate the yam industry and the reason for the dwindling status of yam products in these States, since the active force, the youths are scarcely involved in yam production in the areas of study.

Also, the result indicated that the major type of yam cultivated in the area of study, was the white yam (52.6\%) as a single yam. This accounts for the popularity of white yam in these two states. This finding was in agreement with IITA (2008) report which claimed that out of the 600 known species of yams, that white yam, Dioscorea rotundata, purported to have originated from West Africa, is most popular. It showed a mean annual income of the respondents to be one hundred and fifty thousand, eight hundred and thirty-five naira ( $\$ 150,835.00)$, an indication that yam farmers in the study areas are very poor and that could greatly influence their needs in yam 
production. This supports the position of Odinwa, Albert and Emah (2016) who opined that 'agricultural productions in Nigeria have been in the hands of small scale farmers who are characterized by illiteracy, use of Local varieties/ feeds and poverty'.

Concerning the regularity of contact with extension agents, the result showed that: once per month contact with extension agents $(27.1 \%)$ was dominant in the areas, followed by once per week contact $(25.2 \%)$, while $(24.4 \%)$ had no extension contact at all. This level of contacts was not enough to encourage or motivate ill-considered farmers to adopt a long gestation crop practices like yam so as to boost productivity. That is why Mezirow (2000) emphasized that "Extension agents need to know both the general and specific literacy levels of their targeted audience of farmers in designing and delivering innovative package" which can only be achieved through regular contact with the farmers.

Table 1: Socio-Economic Characteristics of Yam Farmers in Rivers and Imo States

\begin{tabular}{|c|c|c|c|c|c|}
\hline Variables & 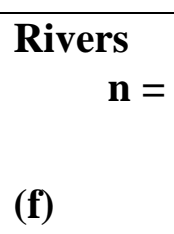 & $\begin{array}{l}\text { State } \\
316 \\
(\%)\end{array}$ & $\begin{array}{l}\text { Imo } \\
\mathrm{n}= \\
\text { (f) }\end{array}$ & $\begin{array}{l}\text { State } \\
271 \\
(\%)\end{array}$ & Mean \\
\hline Sex & (f) & $(\%)$ & (f) & $(\%)$ & \\
\hline Male & 188 & $(59.5)$ & 169 & $(62.4)$ & \\
\hline Female & 128 & $(40.5)$ & 102 & (37.6) & \\
\hline Age & (f) & $(\%)$ & (f) & $(\%)$ & \\
\hline $21-30$ & 15 & (4.7) & 11 & $(4.1)$ & \\
\hline $31-40$ & 74 & (23.4) & 58 & (21.4) & \\
\hline $41-50$ & 131 & (41.5) & 99 & $(36.5)$ & 46 Years \\
\hline $51-60$ & 66 & (20.9) & 60 & $(22.1)$ & \\
\hline Others & 30 & (9.4) & 43 & $(15.9)$ & \\
\hline Marital Status & (f) & $(\%)$ & (f) & $(\%)$ & \\
\hline Single & 54 & (17.1) & 46 & (17.0) & \\
\hline Married & 254 & (80.4) & 219 & $(80.8)$ & \\
\hline Others & 8 & (2.5) & 6 & $(2.2)$ & \\
\hline
\end{tabular}




\begin{tabular}{|c|c|c|c|c|c|}
\hline Level of Education & (f) & $(\%)$ & (f) & $(\%)$ & \\
\hline No Formal education & 32 & $(10.1)$ & 24 & (8.9) & \\
\hline Primary education. & 86 & $(27.2)$ & 77 & (28.4) & \\
\hline Secondary & 139 & $(44.0)$ & 146 & (53.9) & \\
\hline NCE/OND & 41 & (13.0) & 12 & (4.4) & \\
\hline $\mathrm{BSC}-\mathrm{PhD}$ & 18 & $(5.7)$ & 24 & (8.8) & \\
\hline Nature of Farming & (f) & $(\%)$ & (f) & $(\%)$ & \\
\hline Part Time & 121 & $((38.3)$ & 216 & $(79.7)$ & \\
\hline Full Time & 195 & $(61.7)$ & 55 & $(20.3)$ & \\
\hline Farm Size (Hectare) & (f) & $(\%)$ & (f) & $(\%)$ & \\
\hline $0.1-0.5 \mathrm{ha}$ & 36 & $(11.4)$ & 104 & $(38.4)$ & \\
\hline $0.6-1.0 \mathrm{ha}$ & 77 & (24.4) & 108 & (39.9) & \\
\hline 1.1-1.5ha & 141 & $(44.7)$ & 58 & (21.4) & 1.08 ha \\
\hline 1.6-2.0ha & 62 & $(19.6)$ & 1 & (0.4) & \\
\hline $\begin{array}{l}\text { Household } \\
\text { (number) }\end{array}$ & (f) & $(\%)$ & (f) & $(\%)$ & \\
\hline 1- 4 Persons & 56 & $(17.7)$ & 65 & $(24.0)$ & \\
\hline 5-8 Persons & 158 & $(50.0)$ & 108 & (39.9) & $\begin{array}{l}8 \\
\text { members }\end{array}$ \\
\hline 9-13 Persons & 92 & (29.1) & 87 & $(32.1)$ & \\
\hline Others & 10 & $(3.2)$ & 11 & $(4.1)$ & \\
\hline $\begin{array}{l}\begin{array}{l}\text { Types of } \\
\text { cultivated }\end{array}\end{array}$ & (f) & $(\%)$ & (f) & $(\%)$ & \\
\hline White yam & 161 & $(50.9)$ & 148 & (54.6) & \\
\hline Yellow yam & 13 & $(4.1)$ & 11 & (4.1) & \\
\hline Water yam & 7 & $(2.2)$ & 07 & (2.6) & \\
\hline Cocoyam & 25 & (7.9) & 33 & $(12.2)$ & \\
\hline
\end{tabular}




\begin{tabular}{|c|c|c|c|c|c|}
\hline Three leaf yam & 5 & (1.6) & 04 & (1.5) & \\
\hline Combination & 105 & $(33.2)$ & 68 & $(25.1)$ & \\
\hline Annual Income & (f) & $(\%)$ & (f) & $(\%)$ & \\
\hline Below N120, 000 & 68 & $(21.5)$ & 72 & (26.6) & \\
\hline N120,000-N180,000 & 172 & $(54.4)$ & 163 & $(60.1)$ & \\
\hline $\mathrm{N} 181,000-\mathrm{N} 240,000$ & 61 & $(19.3)$ & 35 & (12.9) & N150,835 \\
\hline $\mathrm{N} 241,000-\mathrm{N} 300,000$ & 15 & ( 4.7) & 1 & $(0.4)$ & \\
\hline $\begin{array}{l}\text { Regularity of contact } \\
\text { with Ext. Agent }\end{array}$ & (f) & $(\%)$ & (f) & $(\%)$ & \\
\hline None & 112 & (35.4) & 31 & (11.4) & \\
\hline Weekly & 76 & $(24.1)$ & 83 & (30.6) & \\
\hline Fortnightly & 23 & (7.3) & 32 & (11.8) & \\
\hline Monthly & 55 & $(17.4)$ & 93 & (34.3) & \\
\hline Bimonthly & 21 & ( 6.6) & 15 & $(5.5)$ & \\
\hline Quarterly & 14 & (4.4) & 10 & (3.7) & \\
\hline Yearly & 15 & (4.7) & 7 & (2.6) & \\
\hline Years of Experience & (f) & $(\%)$ & (f) & $(\%)$ & \\
\hline 1-10 Years & 62 & $(19.6)$ & 74 & $(27.3)$ & \\
\hline 11-20 Years & 106 & (33.5) & 89 & $(32.8)$ & 18 years \\
\hline 21-30 Years & 125 & (39.6) & 89 & $(32.8)$ & \\
\hline 31-40 Years & 20 & (6.3) & 17 & (6.3) & \\
\hline 41 Years and above & 3 & $(0.9)$ & 2 & $(0.7)$ & \\
\hline
\end{tabular}

Source: Field Survey, 2018

Where $\mathrm{f}=$ frequency, $\%=$ percent

Result of the Ordinary Least Square (OLS) regression analysis used to test hypothesis 1 (Table 2), depicts that semi log production function was selected as the lead equation for further analysis based on the high value of the coefficient of determination $\left(\mathrm{R}^{2}\right)$, the significant of the coefficient of individual independent variable and signs of the coefficient. The $\mathrm{R}^{2}$ was 0.305 , 
connoting that the independent variables included in the model were able to explain for about $30.5 \%$ of the variation in extension needs output, while the remaining $69.5 \%$ was due to error.

Most of the explanatory variables used in the model such as gender, marital status, nature of farming, household size, cropping practice and contact with extension agents influenced the extension needs output negatively. This finding did not tally with Chayanov (1966) who observed that family size determines the volume of household production and consumption, especially in developing country positively. The coefficient of age, education, types of yam, income and years of experience were significant at 5\% alpha level, meaning that the socioeconomic characteristics of yam farmers especially farmers' age, education, income and experience of farmers affect the extension needs of yam farmers positively in the study areas. This finding was supported by Etim, Thompson and Onyenweaku (2013) who reported that farmers' education, family labour, extension contact and experience of farmers have a positive effect on the farm level technical efficiency and yam output.

Table 2: Result of Regression Analysis on Agro Extension Needs of Yam Farmers in Rivers and Imo States

\begin{tabular}{|lllll|}
\hline Variable & Linear & Semi log & Double Log & Exponential \\
\hline Constant & 75.486 & 64.545 & 1.790 & 1.867 \\
Gender & $(22.415)$ & $(27.973)$ & $(104.309)$ & $(74.238)$ \\
& -0.813 & -2.741 & -0.027 & -0.008 \\
Age & $(-0.956)$ & $(-0.959)$ & $(-1.267)$ & $(-1.248)$ \\
& 3.531 & 25.302 & 0.181 & 0.025 \\
Marital status & $(8.618)^{* * *}$ & $(9.546)^{* * *}$ & $(9.205)^{* * *}$ & $(8.180)^{* * *}$ \\
& -0.340 & -6.277 & -0.040 & 0.000 \\
Education & $(-0.343)$ & $(-1.732)$ & $(-1.479)$ & $(-0.024)$ \\
& 0.868 & 7.564 & 0.071 & 0.009 \\
Nature of farming & $(1.982)^{*}$ & $(2.941)^{* *}$ & $(3.696)^{* * *}$ & $(2.623)^{* *}$ \\
& -5.857 & -18.685 & -0.126 & -0.041 \\
Farm size & $(-6.442)$ & $(-5.978)$ & $(-5.419)$ & $(-6.012)$ \\
& 0.419 & 1.382 & 0.012 & 0.004 \\
& $(1.067)^{*}$ & $(0.651)^{*}$ & $(0.782)^{*}$ & $(1.269)^{*}$
\end{tabular}




\begin{tabular}{|c|c|c|c|c|}
\hline \multirow[t]{2}{*}{ Household size } & -4.380 & -20.878 & -0.149 & -0.031 \\
\hline & $(-7.214)$ & $(-7.642)$ & $(-7.341)$ & $(-6.860)$ \\
\hline \multirow[t]{2}{*}{ Types of yam } & 0.745 & 4.466 & 0.031 & 0.005 \\
\hline & $(4.267)^{* * *}$ & $(3.692)^{* * *}$ & $(3.434)^{* * *}$ & $(3.952)^{* * *}$ \\
\hline \multirow[t]{2}{*}{ Cropping practice } & -0.876 & -2.567 & -0.026 & -0.008 \\
\hline & $(-1.841)$ & $(-1.109)$ & $(-1.495)$ & $(-2.141)$ \\
\hline \multirow[t]{2}{*}{ Income } & 0.401 & 1.288 & 0.007 & 0.003 \\
\hline & $(0.703)^{*}$ & $(0.505)^{*}$ & $(0.389)^{*}$ & $(0.595)^{*}$ \\
\hline \multirow{2}{*}{$\begin{array}{l}\text { Contact with ext, } \\
\text { agents }\end{array}$} & -0.737 & -3.976 & -0.020 & -0.004 \\
\hline & $(-3.291)$ & $(-2.627)$ & $(-1.804)$ & $(-2.460)$ \\
\hline \multirow[t]{2}{*}{ Years of experience } & 0.119 & 1.989 & 0.017 & 0.001 \\
\hline & $(0.208)^{*}$ & $(0.761)^{*}$ & $(0.859)^{*}$ & $(0.272)^{*}$ \\
\hline $\mathrm{R}^{2}$ & 0.302 & 0.305 & 1.790 & 0.277 \\
\hline F Ratio & 20.699 & 20.956 & 19.152 & 18.322 \\
\hline \multicolumn{2}{|c|}{ Source: Field Survey, 2018} & \multicolumn{3}{|c|}{$P<0.05 \%$. Figures in parenthesis are the f-ratio } \\
\hline \multicolumn{5}{|c|}{$\begin{array}{l}\text { Factors that will increase the Productivity of Yam Farmers in Rivers and Imo States } \\
\text { The findings on the factors that will increase the productivity of yam farmers in Rivers and Imo } \\
\text { States showed in high order of increased productivity that: dedicated extension agents (GM - } \\
\text { 3.77) was the highest factor. This points to the fact that yam farmers in the areas believed in } \\
\text { extension, as a panacea to the world indispensable weapon of development in food production } \\
\text { and technology advancement, through their constant introduction of new technologies and follow } \\
\text { ups in farming. This was similar to the findings of Okwoche, Asogwa and Hon (2015) who } \\
\text { recorded a high level of interest in extension education in all areas of crop production by farmers } \\
\text { in Gboko Area in zone 'B' of Benue Agricultural and Rural Development Authority. } \\
\text { Nwachukwu (2013), also supported this claim when he said that the essence of agricultural } \\
\text { extension was to facilitate relationship and nurture synergies within a total information system } \\
\text { involving agricultural research, agricultural education and a vast intricate of information - } \\
\text { providing businesses to farmers. }\end{array}$} \\
\hline \multicolumn{5}{|c|}{$\begin{array}{l}\text { The result also indicated that hybrid seed yams (cultivars) for planting }(\mathrm{GM}=3.72) \text { was another } \\
\text { factor for increased productivity. This is because high yields of yam depend on good planting } \\
\text { material and husbandry, all things being equal (Okezie et al., 2002). }\end{array}$} \\
\hline www.ijaeb.org & & & & Page 171 \\
\hline
\end{tabular}


It further indicated that accessible credit facilities and free extension services ( $\mathrm{GM}=3.63)$, firm promises and full execution of programmes $(\mathrm{GM}=3.61)$, participation in project/programme planning $(\mathrm{GM}=3.60)$, agricultural call centre for information update $(\mathrm{GM}=3.58)$, regular planned workshops $(\mathrm{GM}=3.56)$, rewards for distinguished farmers $(\mathrm{GM}=3.55)$, and skill for processing tubers into finish products $(\mathrm{GM}=3.54)$ would encourage productivity. These findings agree with Izekor and Olumese (2010) who observed that the financial resource is another major constraint to yam production as farmers are poor, and they suffer from limited access to credit of estimating returns on investment and inability of many yam producers to provide the required facilities, thereby impeding higher productivity and output. Also, Zaknayiba and Tanko (2013) affirmed that lack of access to finance and other inputs have negatively affected yam production in the country.

Other factors that will increase productivity of yam farmers from the findings include: introduction of non-stake yam varieties $(\mathrm{GM}=3.49)$, co-existence of the farmers with the extension agents $(\mathrm{GM}=3.44)$, market (for input supply) and field trips exercise with equal grand mean $(\mathrm{GM}=3.43)$, regular visit to farmer's home/farm $(\mathrm{GM}=3.33)$, six months yam varieties $(\mathrm{GM}=3.29)$, and enabling environment $(\mathrm{GM}=3.27)$ among others. These factors are expedient for yam farmer's productivity; for example, non-stake yam varieties will reduce labour and the entire cost of yam production for more profit. This was in consonant with Manyong et al. (2001) who observed that staking has been considered to amplify cost of yam production while vegetation is being constantly removed and causing lack of staking materials or insufficiency and the eventual high cost of staking materials to yam production. Timothy and Bassey (2009) also supported that the development of non-stake yam varieties will encourage more farmers to go back to yam production, thereby increasing total tuber yield.

Also identified, was enabling environment $(\mathrm{GM}=3.27)$, another important factor that should be given priority to farmers in the study areas since thieves do not allow yam farms to thrive in some parts of these states. This claim was supported by Ellis (1992), who observed that peasants produce under very high levels of uncertainty induced by natural hazards (weather, pests, diseases, natural disasters); market fluctuations; and social uncertainty (stealing, insecurity associated with control over resources, such as land tenure and state interventions, and war). These conditions according to him posed risks to peasant production and made farmers very cautious in their decision making.

Table 3: Mean Distribution of Respondents on the Factors that will Increase Productivity of Yam Farmers in Rivers and Imo State

\begin{tabular}{|cccccccc|}
\hline & Rivers & State & Imo & State & Grand & & \\
Needs of yam Farmers & Weighted & Mean & $\begin{array}{c}\text { Weighted } \\
\text { Score }\end{array}$ & Mean & Total & Grand & Remark \\
& Score & $\mathbf{n = 2 7 1}$ & Score & Mean \\
& $\mathbf{n = 3 1 6}$ & & $\mathbf{N}=587$ & \\
\hline
\end{tabular}




\section{International Journal of Agriculture, Environment and Bioresearch}

Vol. 4, No. 06; 2019

ISSN: $2456-8643$

\begin{tabular}{|c|c|c|c|c|c|c|c|}
\hline $\begin{array}{l}\text { Dedicated extension } \\
\text { agents }\end{array}$ & 1167 & 3.69 & 1042 & 3.85 & 2209 & 3.77 & Accepted \\
\hline $\begin{array}{l}\text { Accessible } \quad \text { credit } \\
\text { facilities }\end{array}$ & 1117 & 3.53 & 1012 & 3.73 & 2129 & 3.63 & Accepted \\
\hline Market (for input supply) & 1059 & 3.35 & 947 & 3.50 & 2006 & 3.43 & Accepted \\
\hline $\begin{array}{l}\text { Hybrid seed yams for } \\
\text { planting }\end{array}$ & 1157 & 3.66 & 1024 & 3.78 & 2181 & 3.72 & Accepted \\
\hline $\begin{array}{llr}\text { Skill for processing } \\
\text { tubers } & \text { into } & \text { finish } \\
\text { products } & & \end{array}$ & 1081 & 3.42 & 988 & 3.65 & 2069 & 3.54 & Accepted \\
\hline $\begin{array}{l}\text { Organic method of yam } \\
\text { production }\end{array}$ & 927 & 2.93 & 870 & 3.21 & 1797 & 3.07 & Accepted \\
\hline $\begin{array}{l}\text { Functional farmers } \\
\text { cooperatives }\end{array}$ & 940 & 2.97 & 836 & 3.08 & 1776 & 3.03 & Accepted \\
\hline $\begin{array}{l}\text { Regular visit to farmer's } \\
\text { home/farm }\end{array}$ & 1052 & 3.33 & 901 & 3.32 & 1953 & 3.33 & Accepted \\
\hline Six months yam varieties & 1043 & 3.30 & 888 & 3.28 & 1931 & 3.29 & Accepted \\
\hline $\begin{array}{l}\text { Introduction of non stake } \\
\text { yam varieties }\end{array}$ & 1090 & 3.45 & 955 & 3.52 & 2045 & 3.49 & Accepted \\
\hline Enabling environment & 1041 & 3.29 & 878 & 3.24 & 1919 & 3.27 & Accepted \\
\hline $\begin{array}{l}\text { Co-existence of the } \\
\text { farmers with the } \\
\text { extension agents }\end{array}$ & 1041 & 3.29 & 974 & 3.59 & 2015 & 3.44 & Accepted \\
\hline $\begin{array}{l}\text { Rewards for } \\
\text { distinguished farmers }\end{array}$ & 1073 & 3.40 & 1000 & 3.69 & 2073 & 3.55 & Accepted \\
\hline $\begin{array}{l}\text { Regular } \\
\text { workshops }\end{array}$ & 1089 & 3.45 & 984 & 3.67 & 2073 & 3.56 & Accepted \\
\hline $\begin{array}{l}\text { Management of } \\
\text { environmental hazards }\end{array}$ & & & & & 1927 & & \\
\hline
\end{tabular}


Vol. 4, No. 06; 2019

ISSN: $2456-8643$

$\begin{array}{llllll}1026 & 3.25 & 901 & 3.32 & 3.29 & \text { Accepted }\end{array}$

Participation in

project/programme

planning

Field trips exercise
Free extension services
from cost

$\begin{array}{lllllll}1111 & 3.52 & 994 & 3.67 & 2105 & 3.60 & \text { Accepted }\end{array}$

$\begin{array}{lllllll}1005 & 3.18 & 997 & 3.68 & 2002 & 3.43 & \text { Accepted }\end{array}$

$\begin{array}{lllllll}1106 & 3.50 & 1015 & 3.75 & 2121 & 3.63 & \text { Accepted }\end{array}$

Firm promises and full execution of programmes

$\begin{array}{lllllll}1105 & 3.50 & 1005 & 3.71 & 2110 & 3.61 & \text { Accepted }\end{array}$

Agric. call centre for information update

$\begin{array}{lllllll}1075 & 3.40 & 1019 & 3.76 & 2094 & 3.58 & \text { Accepted }\end{array}$

\section{Source: Field Survey, 2018}

Decision Mean $=2.50$

The $\mathrm{z}$ - test result on the factors that will increase productivity of yam farmers (Table 4) showed $(\mathrm{z}-\mathrm{cal}=4.12)$ and $(\mathrm{z}-$ critical $=1.96)$ at a probability level less than $0.05 \%$. The hypothesis which stated that 'factors that will increase the productivity of yam farmers do not differ significantly between the two states' was rejected, meaning that the extension needs of yam farmers between Rivers and Imo states differed significantly. The difference in the needs of yam farmers between these two states may be due to their different exposure to extension services by different extension agencies handling extension services in their local government areas; agrarian interest of the two state governments and the difference in farmers' social economic status in these states. This finding supported the observation of Nwachukwu (2013) who reported that different types of extension approaches were being practiced in various parts of the world and that each approach reflects a particular set of objectives, aims, clients and socio-cultural setting. The practice of extension today according to Akinola, Issa and Sanni (2011), is dissimilar in that the process is dominated by organizations, and its scope has extended from disjointed local events to a complicated, large scale and even worldwide activity.

Table 4: z-test Result on the Factors that will Increase Productivity of Yam Farmers in Rivers and Imo State

\begin{tabular}{|c|c|c|c|c|c|c|c|}
\hline Source & $\mathbf{N}$ & Mean & df & Variance/Sd & z-cal & z- tab & Remark \\
\hline Rivers & 316 & 67.42 & 585 & $139.37 / 11.81$ & & & \\
\hline Imo & 271 & 71.00 & & $84.70 / 9.20$ & & & \\
\hline Total & 587 & & & & 4.12 & 1.96 & $\mathrm{~S}$ \\
\hline
\end{tabular}




\section{CONCLUSION}

Yam remains one of the important social and traditional staple crops that cannot be displaced in West Africa, especially in the areas of study, yet the youths are not involved in the production. Yam farmers in Rivers and Imo States need dedicated extension agents, hybrid seed yams for planting, accessible credit facilities, participation in project/programme planning concerning them, introduction of non-stake yam varieties, short gestation yam varieties, functional farmers' cooperatives, practicable encouragements from government, youths' participation in yam production and enabling environment, among other factors to increase yam productivity and live well.

\section{RECOMMENDATIONS}

Based on the findings, this study recommended the following:

1. The youths should be encouraged and armed financially to meaningfully engage in yam production by the State governments, non-governmental organizations and philanthropic individuals interested in agriculture in these two States,

2. Only qualified and dedicated extension agents should be employed in the field of agriculture to handle technical extension services especially in yam production in these two States,

3. A unified extension package involving the State Ministries of Agriculture, nongovernmental agro agencies, extension professionals and the yam farmers should be developed for these states, to encourage uniformity in extension method and service delivery in yam production,

4. Rewards for distinguished yam farmers should be introduced to encourage hard work among yam farmers in these two states, and

5. Special but accessible credit facilities, devoid of politics should be made available to yam farmers on-the-farm (real farmers) only, in these two states and the mechanism for credits assessment and supervision be assigned to agro extension professionals.

\section{REFERENCES}

Akinola, M., Issa, F. \& Sanni, S. (2011). Agricultural extension systems in West Africa:Adoptable strategies for Nigeria's. Journal of Agricultural Extension. 1- 7.

Anyanwu C.N. (1986). Community education: The African dimension. Ibadan: De partment of Adult Education, University of Ibadan.

Baudura, A. (1986). Social foundations of thought and action: A social cognitive theory. In Braun, B., McCoy, T., and Finkbeiner, N. (2014). Extension education theoretical framework with criterion-referenced assessment tools. College Park, MD: University of Maryland Extension. Englewood Cliffs, NJ: Prentice-Hall, Inc. 
Baumgartner, L. (2001). An update on transformational learning. In The new update on adult learning theory: New directions for adult and continuing education, 89. San Francisco: Josey-Bass.

Chayanov, A. V (1966). The theory of peasant economy. American Economic Association Translation Series.

Ellis, D. G. (1992). Syntactic and Pragmatic Codes in Communication. Wiley online Library.

Etim, N. A., Thompson, D. \& Onyenweaku, C. E. (2013). Measuring efficiency of yam (Dioscorea spp.) production among resource poor farmers in rural Nigeria. Journal of Agriculture and Food Sciences, 1(3): 42-47.

Food and Agricultural Organization (F.A.O, 2015). FAOSTAT database. [Online]. Available at: http://bit.ly/NmQzZf. Accessed: 10. April 2015.

F.A.O. (2017). Production year book, Food and Agriculture Organization of the United Nations Organization, Rome.

Fasasi, A.R. (2006). Resource Use Efficiency in Yam Production in Ondo State, Nigeria. Agricultural Journal, 1(2): 36-40.

IITA (International Institute of Tropical Agriculture) (1982). IITA Annual Report International institute of Tropical Agriculture, Ibadan, Nigeria.

IITA (International Institute of Tropical Agriculture (2008). AGXE analysis provides vital insight for IITA crops. IITA Research. 12-29.

Izekor, O. B. \& Olumese, M. I. (2010). Determinants of yam production and profitability in Edo State, Nigeria. African Journal of General Agriculture, 6(4): 205-21.

Kushwaha, S. \& Polycap, I.M. (2001). Economics of Small Scale Yam Production in Quaian Pau L.G.A. of Plateau State. Proceedings of $39^{\text {th }}$ Annual Conference of ASN, ATBU, Bauchi, October 15-19. 69-74.

Ladele, A. A. \& Chah J. M. (2014). Sampling techniques in agricultural extension research. A Guide to Research in Agricultural Extension. Agricultural Society of Nigeria. $35-53$.

Manyong, V. M., Asiedu, R \& Olaniyan, G. O. (2001). Farmers perception of and actions on, resources management constraints in the yam based systems of Western Nigeria In: Akoroda, M.O. and Ngeve, J.M (compilers) Root Crops in the $21^{\text {st }}$ century. Proceeding of the $7^{\text {th }}$ Triennial Symposium of the International society for Tropical Root Crops-African Branch, held at the Centre of International Conferences, Cotonou, Benin, 11-17 October, 1998. 156-167. 
Martin, A. R. (1988). Teaching Competences Needed in Extension Workers in transfering Agricultural Technologies to Malaysian Farmers. Journal of Agricultural Education .

Mendola, M. (2007). Migration and technological change in rural households: Complements or substitutes. Journal of Development Economics. 24(1). 4968.

Mezirow, J. (Ed.). (2000). Learning as transformation: Critical perspectives on a theory in progress. San Francisco: Jossey-Bass.

Nwachukwu, I. (2013). Agricultural Extension and Rural Sociology: Promoting Indigenous Knowledge. Lagos: Mbeyi \& Associates (Nig) Ltd.

Odinwa, A. B. \& Nlerum, F. E. (2015). Socio-economic effects of using the law enforcement agents in controlling community conflicts in Rivers State, Nigeria. International Journal of Pure and Applied science (IJPAS). 94-103

Odinwa, A. B., Emah, G. N. \& Odinwa, A. N. (2016). Challenges of Rabbit Farming in Ogba/Egbema/ Ndoni Local Government Area of Rivers State. Intenational Journal of Agriculture and Earth Science, 6-13.

Odinwa, A. B., Albert, C. O. \& Emah, G. N. (2016). Assessment of agro-credits available to farmers' in Orashi Region of Rivers State, Nigeria. Journal for Applied Research (JFAR), 8 (1). 77 - 94.

O'Hair, S. K. (1996). Tropical Root and Tuber crops. Portland: Timber Press.

Okezie, N. K., Manyong, V.M., Coulibaly, O. \& Asiedu, R. (2002). Estimating market demand for fresh yam characteristics using contingent valuation: implications for crop breeding and production choices, Agricultural Economics, 39. 349-363.

Okwoche, V. A. \& Asogwa, B. C. (2015). Assessment of extension education needs of crop farmers in Zone 'B' Area of Benue Agricultural and Rural Development Authority (BNARDA), Benue State, Nigeria. American International Journal of Social Science. 4(2).

Redmond, B.F. (2010). Need Theories: What do I want when I work? Work Attitudes and Motivation. The Pennsylvania State University World Campus.

Scott, G. J. R., Rosegrant, M. \& Bokanga, M. (2000). Roots and Tubers in the Global Food System Vision Statement of Year 2020. International Potato Centre, Lima Peru. 67-70. 
Stephens, J. M. (2009). Horticultural Sciences. Department of Community Extension Service, Institute of Food and Agricultural Science. University of Florida, Gaines Ville.

Timothy, G. F \& Bassey E. E. (2009). Preliminary study on the effect of tuber sett weight derived from regions of seed yam on growth and yield of yam in south-eastern Nigeria. Nigerian Journal of Agricultural Technology 21: 32 40.

Uwe, J. N. (2002). Alternative approaches to organizing extension" in FAO Agricultural Extension www. Org/docrep/W5830EAV5830e o.4.htm.

Zaknayiba, D. B. \& Tanko, L. (2013). Costs and returns analysis of yam production among small scale farmers in Karu local government area, Nasarawa State, Nigeria. PAT, 9(1): 73-80.Contact information. 